\title{
The good, the bad and the ugly: The shifting ethical stance of Malaysian consumers
}

\author{
Teck-Chai Lau \\ Universiti Tunku Abdul Rahman (Malaysia) \\ lautc@utar.edu.my
}

Received April, 2009

Accepted September, 2010

\begin{abstract}
:
Due to the recent business ethical problems in Malaysia such as tax fraud, deceptive advertising, production of unsafe products and copyright piracy, the current research aim to examine ethical issues in the marketplace from the perspective of consumers. There are three objectives of this research. The first objective is to investigate the effect of moral ideologies and Machiavellianism on consumer ethical beliefs. The second objective is to determine which of these ideologies exert the greatest influence on consumer ethical beliefs and the third objective is to discover whether Malaysian consumers have evolved in their ethical stance over the last ten years. The dependent variable in this research is the recently modified consumer ethics scale developed by Vitell and Muncy (2005). An online survey was adopted as data collection method as it was inexpensive, fast and could ensure high response rates. However it has several limitations such as the possible non-representativeness of Internet respondents to the Malaysian population and higher non-response error. The results indicated that idealism exerted the greatest influence on all the four dimensions of consumer ethics. It was also revealed that Malaysian consumers had evolved over the past ten years in their moral ideology: from relativism to idealism.
\end{abstract}

Keywords: consumer ethics, idealism, relativism, Machiavellianism, Malaysia.

JEL Codes: M31 


\section{I ntroduction}

Ethics has received increased attention from the private and public sectors as well as from the academics over the past several decades. In the West, the highly publicized incidents at Enron, Arthur Anderson and WorldCom have brought the topic of ethics particularly business ethics to the public's attention. The recent collapse of financial institutions in America notably Lehman Brothers and AIG Group due to the sub-prime mortgage scandals sent "economic tsunami" across the world. This resulted in an unprecedented financial meltdown dubbed by many as the worst economic crisis since the Great Depression. The devastating impact of the US-led global financial catastrophe is taking a heavy toll on the rest of the world and with it, asset and equity values have taken a severe beating. The wealth destruction has significantly weakened consumers' confidence.

There are several reasons why this study is pertinent especially in Malaysia. In the first seven months of 2010, the Malaysian Anti Corruption Commission (MACC) received 7,224 cases of allegations of corrupt practices involving transactions of RM6. 2 million in cash. A total of 510 people with the bulk from public sector were arrested. Also among those who were detained were private sector employees, members of the public and several politicians (The STAR, 2010). Furthermore despite measures taken by the Malaysian Government to curb corruption, there is little change in Malaysia's corruption index ratings. Transparency International publishes the annual Corruption Perceptions Index (CPI), which measures the perception of corruption in participating countries. Malaysia has participated in the study since its inception in 1995 and distressingly, the country's rankings appear to be steadily declining, from the 23rd spot in 1995 to 47th in 2008 (The STAR, 2009).

Considering the recent ethical environment in Malaysia where ethical violations involving politicians and business professionals are common practice and the country is suffering from a number of ethical problems such as tax fraud, deceptive advertising, production of unsafe products and copyright piracy, the current research is therefore timely to examine ethical issues in the marketplace from the perspective of the consumers. Rao and Al-Wugayan (2005) pointed out that there is a growing interest in researching consumer ethics. Despite of this, there seems to be a dearth of consumer ethics studies in the context of Malaysia. 


\section{- Intangible Capital}

Intangible Capital, 2010 - 6(2): 236-257 - ISSN: 1697-9818 doi:10.3926/ic.2010.v6n2.p236-257

Most of the major corporate scandals received wide coverage and publicity in the media. Unfortunately in most cases corporations and big businesses were portrayed as perpetrators preying on the helpless consumers. However, research indicates (Al-Khatib et al., 1997; Fullerton et al., 1997; Wikes, 1978) that consumers are not only victims but are also victimizers. A recent report stated that retail crime in the EU and central Europe cost 29,038 million Euros which amounts to 71.23 Euros for every person (European Retail Theft Barometer, 2006). Several 'hidden' crimes such as home copying and file sharing continue to impose major losses on recording and software industries. This 'criminality of the good' can be found in most countries and is increasing (Silverman, 1999). As Bernstein (1985: 24) pointed out, consumers are 'out-doing big business and the government at unethical behavior'. Understanding why some consumers engage in an unethical behavior may be helpful in ultimately curtailing such practices. Hence, it is pertinent to study consumer behavior in ethics research so as to gain a complete understanding of ethical issues in the marketplace (Vitell, 2003).

Ethical issues involving consumers are as important as ethical issues concerning major corporations as consumers are a major partaker in market interaction. Vitell et al. (1991) emphasize that there is a 'gap' in the marketing ethics literature concerning the ethical beliefs and attitudes of the final consumers regarding potentially unethical consumer practices. Consumers are also the major contributors in the business process and not considering them in ethics research may result in an incomplete understanding of the buyer-seller dyad.

There are three objectives of this research. The first objective is to investigate the effect of moral ideologies and Machiavellianism on consumer ethical beliefs. The second objective is to determine which of these ideologies exert the greatest influence on consumer ethical beliefs. Finally the third objective is to discover whether Malaysian consumers have evolved in their ethical stance in the last ten years. This paper will begin by providing a theoretical background of the relevant literature. Thereafter the methodology and the results from the quantitative study will be presented. The paper will conclude with a discussion of the findings and limitations for future improvement. 


\section{Literature Review}

\section{Moral I deologies}

There are two distinct dimensions of moral ideologies: idealism and relativism (Forsyth, 1992). Moral idealism refers to the extent to which a person focuses on the inherent rightness or wrongness of an action regardless of the consequences of that action. In making moral judgments, moral idealists use idealistic rather than practical criteria. Moral idealists take the position that harming others is universally and always bad and should be avoided. Those who are less idealistic believe that harm is sometimes necessary to produce good. They are inclined to take a utilitarian perspective, perceiving that an act is right if it produces the greatest good for the greatest number of people affected by the action, even though it may be harmful to certain group of people (Forsyth, 1992).

Moral relativism is the belief that all moral standards are relative to the culture in which they take place (Schlenker \& Forsyth, 1977). Relativism is the degree to which an individual rejects universal moral rules when making ethical judgments. For a relativist, moral rules cannot be derived from universal principles, but exist as a function of time, place and culture. Relativists weigh the circumstances when evaluating others rather than the ethical principles that were violated. As a result, no set of rules can be formulated to determine what is right and what is wrong for all people. This moral judgment can differ from person to person and from one situation to another (McGee, 1992).

Most research suggested that idealism is associated with greater ethicality and relativism with lower ethicality. Rawwas et al. (1995) found that Hong Kong consumers who scored high on idealism were inclined to view all types of questionable consumer actions as less moral than Northern I reland consumers who scored low on idealism. Erffmeyer et al. (1999) discovered that Japanese consumers who scored high on idealism were least likely to engage in questionable consumer activities. Kenhove et al. (2001) reported that individuals with higher scores on idealism tend to have higher ethical beliefs. Singhapakdi et al. (1995) concluded that idealism positively influences marketers' perceptions on the importance of ethics and social responsibility while relativism had the opposite effect. In another study, Singhapakdi et al. (1999) confirmed that less idealistic and more relativistic Malaysian consumers were less sensitive to unethical marketing practices than the US consumers. 


\section{- Intangible Capital}

Intangible Capital, 2010 - 6(2): 236-257 - ISSN: 1697-9818

doi:10.3926/ic.2010.v6n2.p236-257

Based on past findings, it is expected that consumers who are more idealistic would be more likely to reject questionable activities than consumers who are less idealistic. Similarly, it is expected that individuals who are more relativistic would be less likely to reject questionable activities than consumers who are less relativistic.

\section{Machiavellianism}

A study by Calhoon (1969: 206) attested that a Machiavellian is "one who employs aggressive, manipulative, exploiting and devious moves in order to achieve personal or organizational objectives. These moves are undertaken according to perceived feasibility with secondary considerations to the feelings, needs and/or rights of others". The label Machiavellian is becoming a negative epithet, indicating at least an amoral (if not immoral) way of manipulating others to accomplish one's objectives (Hunt \& Chonko, 1984). Christie and Geis (1970) developed the MACH IV scale to measure Machiavellianism. They concluded that high score on the MACH scale indicated an individual who tend to manipulate more, win more, is less persuaded and influence others more than those who score lower on the same scale. The study also reported that individuals with high Machiavellian tend to exhibit a relative lack of involvement in interpersonal relationships and concern with conventional morality. This lack of attachment with others, leads the more Machiavellian personality to be more accepting of potentially less ethical consumer practices. Numerous studies have investigated the impact of Machiavellianism on consumers' ethical perceptions (Al-Khatib et al., 1997; Chan et al., 1998; McHoskey et al., 1999; Muncy \& Vitell, 1992; Rawwas, 2001; Rawwas \& Singhapakdi, 1998). The conclusions of these studies suggest that the higher the individual's Machiavellianism tendencies, the less likely that individual will perceive unethical or questionable actions negatively.

Based on the theoretical and empirical literature, the following research question is formulated:

RQ1: Which of these ideologies (relativism, idealism, Machiavellianism) exert the greatest influence on consumer ethical beliefs? 


\section{Consumer ethics}

Taylor (1975: 1) define ethics as the "inquiry into the nature and grounds of morality where the term morality is taken to mean moral judgments, standards and rules of conduct." There were several definitions of consumer ethics. While Dodge et al. (1996) define consumer ethics as the "rightness as opposed to the wrongness of certain actions on the part of the buyer or potential buyer in consumer situations," Muncy and Vitell (1992: 298) define it as "the moral principles and standards that guide behavior of individuals as they obtain, use and dispose of goods and services."

A number of recent researchers (Swaidan et al., 2004; Vitell, 2003) highlighted that although there is a large body of empirical research concerning ethics in the market place, most of them focused on the seller rather than the buyer side of the equation. Rao and Al-Wugayan (2005) stressed that marketing is an exchange process between buyers and sellers, and both parties can exhibit unethical behaviors. Therefore, ignoring consumers may result in an incomplete understanding of that process (Vitell, 2003) and in the development of ineffective marketing strategies (Swaidan et al., 2004). This has resulted in consumer ethics becoming an important area for research in the last decade (Steenhaut $\&$ Kenhove, 2006).

The original consumer ethics scale by Muncy and Vitell (1992) consists of four distinct dimensions: (1) actively benefiting from illegal activities, (2) passively benefiting, (3) actively benefiting from deceptive but legal practices and (4) no harm activities. The first dimension signifies the behavior in which the consumers actively taking advantage of a situation at the expense of the seller. For example, a customer gives misleading price information to cashier when the price tag has been peeled off. The second dimension consists of a situation where consumers passively benefiting themselves due to the seller's mistake. An example of this situation is when a customer gets too much change and does not inform the cashier. The third dimension represents actions in which consumers actively involved in unethical but not necessarily illegal practices. For example, a customer keeps quiet when a waitress at the fast food restaurant serves him first instead of the other customer lining up in front of him. The final dimension refers to the behavior that is not seen as harmful to others. An example of this situation is the act of spending an hour trying on different shoes and not purchasing any. 


\section{- Intangible Capital}

Intangible Capital, 2010 - 6(2): 236-257 - ISSN: 1697-9818

doi:10.3926/ic.2010.v6n2.p236-257

Many individual factors influence consumers' ethical behaviors. A number of researchers have studied some of these factors such as demographic factors (Ang et al., 2001; Muncy \& Vitell, 1992; Rawwas, 1996; Rawwas \& Singhapakdi, 1998), cultural environment (Al-Khatib et al., 1997; Polonsky et al., 2001; Rawwas et al., 1994, 1996) and personal values (Kenhove et al., 2001; Strutton et al., 1994; Thong \& Yap, 1998; Vitell et al., 2001). Several personal characteristics were tested as factors influencing ethical behavior. Among the most frequently studied factors are Machiavellianism (Erffmeyer et al., 1999; Kenhove et al., 2001; Rawwas et al., 1994, 1996;) and moral ideologies (Al-Khatib et al., 2002; Erffmeyer et al., 1999; Rawwas et al., 1995; Singhapakdi et al., 1999; Swaidan et al., 2004). Overall, Vitell (2003) points out that less Machiavellian, less relativistic and more idealistic consumers were found to be more ethical.

In 2005, the consumer ethics scale was modified and a new dimension that represents consumers' desire to recycle products and 'do the right thing' was added (Vitell \& Muncy, 2005). An example of this situation is not purchasing products from companies that consumers believe are not treating their employees fairly. Review through the literatures discovered that none of the subsequent empirical research on consumer ethics adopts the modified Vitell and Muncy (2005) scale. All past studies utilized Muncy and Vitell (1992) consumer ethics scale. Furthermore there seems to be a dearth of consumer ethics research in the Malaysian context. Singhapakdi et al. (1999) did a research comparing Malaysian consumers with the US consumers. The study found that Malaysian consumers in 1999 tend to be less idealistic and more relativistic in their moral philosophies than US consumers. Furthermore the study also discovered that Malaysian consumers were less sensitive to unethical marketing practices than US consumers. A more recent study by Lau et al. (2009) using student sample revealed that Malaysian young consumers were idealistic. The ethical climate in Malaysia has changed much since Singhapakdi et al. (1999) research. Thus, the second research question is formulated as follows:

RQ2: Have Malaysian consumers evolved in their ethical stance over the last ten years?

The current study used Vitell and Muncy (2005) consumer ethics scale that include all the five dimensions and a wider sample of the Malaysian population. 


\section{- Intangible Capital}

Intangible Capital, 2010 - 6(2): 236-257 - ISSN: 1697-9818

doi: 10.3926/ic.2010.v6n2.p236-257

In summary, based on past findings, consumers who are more idealistic are expected to reject questionable activities than consumers who are less idealistic. Similarly, it is also expected that individuals who are more relativistic would be less likely to reject questionable activities than consumers who are less relativistic. For individual's having higher Machiavellianism tendencies, it would be less likely that this individual will perceive unethical or questionable actions negatively. The current research fits into consumer ethics research by extending the study to the Malaysian consumers and also comparing the outcome of the research to past studies especially the research conducted by Singhapakdi et al. (1999).

\section{Research Methodology}

\section{Research instruments}

The survey consisting of three major parts was administered to respondents. The first part of the survey, Muncy-Vitell Questionnaire (MVQ) presented the participants with a set of situations that entailed ethical content. Items were measure on a five-point scale with 1 indicating, "strongly believe that it is wrong" and 5 indicating, "strongly believe that it is not wrong."

The second part of the survey measured the moral ideologies (idealism vs. relativism) using the Ethical Position questionnaire (EPQ) developed by Forsyth (1980). Machiavellianism was also measure in this section using the MACH IV scale developed by Christie and Geis (1970). Respondents were asked to indicate their agreement or disagreement with each item using a five point-Likert format where a 5 indicated strong agreement. The third part of the survey measured the demographics of the participants.

To address the first research question on discovering which of the ideologies (relativism, idealism, Machiavellianism) exerted the greatest influence on consumer ethical beliefs, regression analyses will be conducted. To address the second research question whether Malaysian consumers evolved in their ethical stance over the last ten years, a direct comparison of the current study with the research done by Singhapakdi et al. (1999) will be carried out. 


\section{Data collection and characteristics of respondents}

Data collection was administered through convenience and snowball sampling method. An online questionnaire was designed and posted on the social network sites such as Facebook and personal blogs. This method was chosen because it was inexpensive, fast and could ensure high response rates (McDaniel \& Gates, 2008). However, it was not without limitations. Several limitations associated with this method were the possible non-representativeness of Internet respondents to the Malaysian population and higher non-response error (McDaniel \& Gates, 2008; Zikmund, 2003). However as seeking generalization is not the main aim of the research, the advantages of using online survey method outweighs its disadvantages.

\begin{tabular}{|c|c|c|c|}
\hline Variables & Percentage & Variables & Percentage \\
\hline $\begin{array}{l}\text { Male Gender } \\
\text { Female }\end{array}$ & $\begin{array}{l}48 \% \\
52 \%\end{array}$ & $\begin{array}{l}\quad \text { Education } \\
\text { Secondary } \\
\text { Undergraduate } \\
\text { Postgraduate } \\
\text { Others }\end{array}$ & $\begin{array}{l}19 \% \\
51 \% \\
23 \% \\
7 \%\end{array}$ \\
\hline $\begin{array}{l}\text { Age } \\
\text { Below } 18 \\
18 \text { to } 29 \\
30 \text { to } 44 \\
\text { Above } 44\end{array}$ & $\begin{array}{l}1 \% \\
48 \% \\
35 \% \\
17 \%\end{array}$ & $\begin{array}{l}\quad \text { Occupation } \\
\text { Student } \\
\text { Technical } \\
\text { Management } \\
\text { Sales and Marketing } \\
\text { Others }\end{array}$ & $\begin{array}{l}16 \% \\
24 \% \\
14 \% \\
20 \% \\
27 \%\end{array}$ \\
\hline $\begin{array}{l}\quad \text { Marital status } \\
\text { Single } \\
\text { Married } \\
\text { Divorced }\end{array}$ & $\begin{array}{l}60 \% \\
38 \% \\
2 \%\end{array}$ & $\begin{array}{l}\quad \text { Location of residence } \\
\text { East Malaysia } \\
\text { West Malaysia }\end{array}$ & $\begin{array}{l}51 \% \\
49 \%\end{array}$ \\
\hline
\end{tabular}

Table 1. Demographic characteristics of respondents $(N=289)$

Respondents were requested to participate in the online survey and were encouraged to forward the survey to their network of friends. Those who participated in the survey were assured anonymity and no remuneration was given. At the end of the survey period, a total of 343 respondents submitted the selfadministered questionnaire. However only 289 ( 84.3 percent) were useable for the purpose of this study. A total of 54 respondents were not included as their survey questionnaires were considered as incomplete. Hair et al. (2007: 305) said that the general rule of thumb for eliminating an entire questionnaire is when the proportion of missing data exceeds 10 percent of the total responses'. The high proportion of incomplete questionnaire was also due to the method of data collection through online survey, where callback and follow-up on non response items were not possible. The demographic characteristics of the respondents are shown in Table 1. 


\section{Results}

\section{Factor analysis}

\begin{tabular}{|c|c|c|}
\hline Dimension and items & Factor loading & Cronbach Alpha \\
\hline $\begin{array}{l}\text { Actively benefiting from illegal activities (CE1) } \\
\text { - Drinking a can of soda in a supermarket without paying } \\
\text { for it. } \\
\text { Reporting a lost item as "stolen" to an insurance } \\
\text { company in order to collect the money. } \\
\text { - Giving misleading price information to a clerk for an un- } \\
\text { priced item. }\end{array}$ & $\begin{array}{l}0.667 \\
0.525 \\
0.605\end{array}$ & 0.743 \\
\hline $\begin{array}{l}\text { Benefiting from questionable activities (CE2) } \\
\text { - } \quad \text { Using an expired coupon for merchandise. } \\
\text { - } \quad \text { youing nothing when a waitress miscalculates a bill in } \\
\text { - } \quad \text { Lying about a child's age in order to get a lower price. } \\
\text { - } \text { automobile. } \\
\text { - Getting too much change and not say anything. } \\
\text { - } \quad \text { maying counterfeit goods instead of buying the original } \\
\text { - } \quad \text { Stretching the truth on an income tax return. }\end{array}$ & $\begin{array}{l}0.713 \\
0.620 \\
0.611 \\
0.609 \\
0.608 \\
0.437 \\
0.405\end{array}$ & 0.842 \\
\hline $\begin{array}{l}\text { No harm / no foul (CE3) } \\
\text { - Copying computer software or games that you did not } \\
\text { buy } \\
\text { "Burning" a CD instead of buying it. } \\
\text { - Downloading music from the Internet instead of buying } \\
\text { it. }\end{array}$ & $\begin{array}{l}0.727 \\
0.838 \\
0.769\end{array}$ & 0.886 \\
\hline 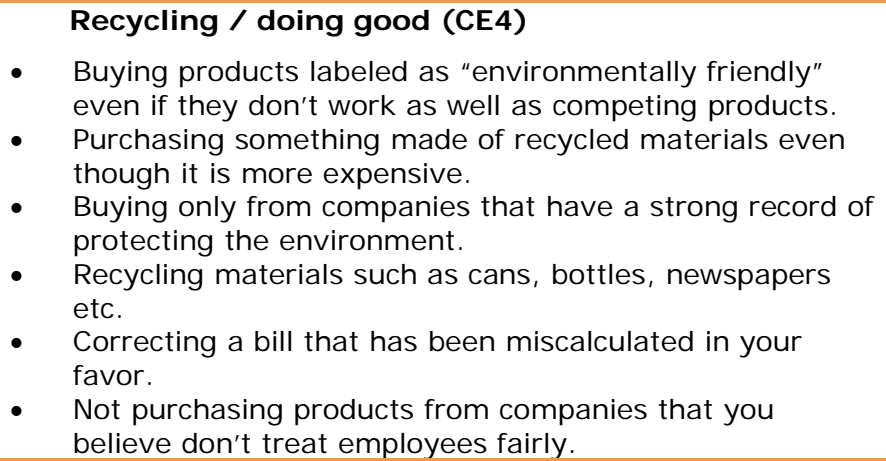 & $\begin{array}{l}0.653 \\
0.666 \\
0.484 \\
0.733 \\
0.596 \\
0.523\end{array}$ & 0.744 \\
\hline
\end{tabular}

Table 2. Factor analysis for consumer ethics scales

As a preliminary analysis, the dependent variable was factor analyzed to reduce the numerous variables to a manageable number of components. Factoring ceased when all eigenvalues of greater than one were obtained and when a set of factors explained a large percentage of the total variance was achieved. A principal components factor analysis was performed on the consumer ethics scale developed by Vitell and Muncy (2005). The Kaiser-Meyer-Olkin test (index: 0.864) and Bartlett's test of sphericity (Barlett's $=2500.114, p<0.001$ ) indicated that these data were deemed fit for factor analysis. Based on the guidelines by Hair et al. (1998), the factor analysis showed that: (1) all research variables exceeded the The good, the bad and the ugly: The shifting ethical stance of Malaysian consumers 
acceptable standard of Kaiser-Meyer-Olkin's value of $0.6,(2)$ all research variables were significant in Bartlett's test of sphericity, (3) all research variables had eigenvalues larger than 1 , and (4) the items for each research variable exceeded factor loadings of 0.40 . The factor solution indicated that 48.695 percent of the total variance was explained by the four consumer ethics factors.

In summary, in the Malaysian context, the first dimension of consumer ethics comprised of four items and was labeled as "actively benefiting from illegal activity". The second dimension was labeled as "benefiting from questionable activities" and comprised of seven items. The third dimension included 3 items and was labeled, as "no harm/ no foul". Finally the fourth dimension was labeled as recycling/ doing good comprised of 6 items and was similar with the dimension proposed by Vitell and Muncy (2005). The results of the factor analysis can be seen in Table 2.

Overall, the findings of the factor analysis support the relatively consistent factor structure of Vitell and Muncy (2005) dimensions for consumer ethics. Table 3 shows the comparison of consumer ethics dimension in Muncy and Vitell (1992), Vitell and Muncy (2005) and the current study after factor analysis.

\begin{tabular}{|c|c|c|c|}
\hline No & $\begin{array}{l}\text { Consumer ethics dimensions } \\
\text { (Muncy and Vitell, 1992) }\end{array}$ & $\begin{array}{c}\text { Consumer ethics dimensions } \\
\text { (Vitell and Muncy, 2005) adopted } \\
\text { in this research }\end{array}$ & $\begin{array}{l}\text { Dimensions after factor } \\
\text { analysis }\end{array}$ \\
\hline 1 & $\begin{array}{l}\text { Actively benefiting from illegal } \\
\text { activities }\end{array}$ & $\begin{array}{l}\text { Actively benefiting from illegal } \\
\text { activities }\end{array}$ & $\begin{array}{l}\text { Actively benefiting } \\
\text { from illegal activities } \\
\text { (CE1) }\end{array}$ \\
\hline 2 & Passively benefiting & Passively benefiting & \multirow{2}{*}{$\begin{array}{l}\text { Benefiting from } \\
\text { questionable activities } \\
\text { (CE2) }\end{array}$} \\
\hline 3 & $\begin{array}{l}\text { Actively benefiting from } \\
\text { deceptive but legal practices }\end{array}$ & $\begin{array}{l}\text { Actively benefiting from deceptive } \\
\text { but legal practices }\end{array}$ & \\
\hline 4 & No harm / no foul activities & No harm / no foul activities & $\begin{array}{l}\text { No harm / no foul } \\
\text { (CE3) }\end{array}$ \\
\hline 5 & Nil & Recycling / doing good & $\begin{array}{l}\text { Recycling / doing good } \\
\text { (CE4) }\end{array}$ \\
\hline
\end{tabular}

Table 3. Comparison of consumer ethics dimensions.

\section{Reliability Analysis}

A reliability assessment of all measures of the study was carried out. The observed reliability coefficients (Cronbach's alpha) were 0.868 for idealism, 0.808 for relativism, 0.602 for Machiavellianism. For the consumer ethics dimensions, the The good, the bad and the ugly: The shifting ethical stance of Malaysian consumers 


\section{- Intangible Capital}

I ntangible Capital, 2010 - 6(2): 236-257 - ISSN: 1697-9818 doi: 10.3926/ic.2010.v6n2.p236-257

reliability of the measures were 0.743 for "actively benefiting from illegal activities", 0.842 for "benefiting from questionable activities", 0.886 for "no harm/ no foul" and 0.744 for "recycling/ doing good". The Cronbach alpha reliability for Machiavellianism was 0.602 . This does not compare well with similar studies in Western cultures (Christie \& Geis, 1970; Chonko \& Hunt, 1985; Vitell et al., 1991) that resulted in alphas higher than the recommended 0.70 for reliability coefficients (Nunnally, 1978). Some studies have reported lower reliability coefficients for the $\mathrm{MACH}$ IV scale, but went on to apply the measure in subsequent assessment of ethical ideologies (Bonsu \& Zwick, 2007; Erffmeyer et al., 1999; Rawwas, 1996; Shen \& Dickson, 2001). Based on past studies, this was deemed acceptable and Machiavellianism was used in subsequent analysis.

\section{Regression Analysis}

Four regression equations were developed to determine the relationship between the respondents' perceptions of ethical behavior in a consumer context with moral ideologies and mach. Table 4 shows the results for each dimensions.

\begin{tabular}{|l|c|c|c|c|c|}
\hline \multirow{2}{*}{ Dependent Variables } & \multicolumn{4}{|c|}{ I ndependent Variables (Beta Coefficients) } \\
\cline { 2 - 6 } & Relativism & I dealism & MACH & R $^{2}$ & Sig. F \\
\hline $\begin{array}{l}\text { Actively benefiting from } \\
\text { illegal activities (CE1) }\end{array}$ & 0.025 & $-0.325^{*}$ & $0.184^{*}$ & 0.144 & $15.988^{*}$ \\
\hline $\begin{array}{l}\text { Benefiting from } \\
\text { questionable activities } \\
\text { (CE2) }\end{array}$ & 0.082 & $-0.267^{*}$ & $0.234^{*}$ & 0.135 & $14.831^{*}$ \\
\hline $\begin{array}{l}\text { No harm / no foul (CE3) } \\
\text { Recycling / doing good } \\
\text { (CE4) }\end{array}$ & 0.070 & $-0.136^{*}$ & $0.132^{*}$ & 0.041 & $4.064^{*}$ \\
\hline
\end{tabular}

* Significant at $p<0.05$

Table 4. Results of regression analysis.

For the dimension "Actively benefiting from illegal activities" (CE1), relativism, idealism and Machiavellianism explained 14.4 percent of the variance in the dependent variable. Idealism was found to be the most influential variable in this equation $(\beta=-0.325, p<0.05)$. The direction of the sign indicates an inverse relationship between an idealistic moral ideology and engaging in illegal activities. This implies that Malaysian consumers who function under a primarily idealistic moral ideology were least likely to engage in illegal activities as part of their 


\section{- Intangible Capital}

I ntangible Capital, 2010 - 6(2): 236-257 - ISSN: 1697-9818 doi:10.3926/ic.2010.v6n2.p236-257

consumer behavior. Consumers ascribing to Machiavellianism would be more likely, as indicated by the sign, to initiate an illegal activity from which they would benefit $(\beta=0.184, p<0.05)$. However, in comparing the effect between idealistic ideology and Machiavellianism as measured by the standardized Beta coefficients, it shows that idealistic ideology exerts more influence in a situation involving illegal consumer activities. This seems to support the concept that, within the Malaysian consumer culture, the acceptance of actively benefiting from illegal actions, for a Machiavellistic individual was less powerful compared to the influence of an idealistic person. In the case of relativism, it was not a significant factor in the first prediction model.

In the second equation, consumers stand to benefit from questionable activities (CE2). In this scenario, the three independent variables explained 13.5 percent of the variance in the response to the presented ethical situations $\left(R^{2}=0.135\right)$. For these situations, the idealism construct, assumes the greatest role in explaining the variance in consumer actions $(\beta=-0.267, p<0.05)$. Those ascribing to Machiavellianism would be prone to find acceptable those situations in which the consumer might benefit from questionable activities. Similar to the first model, relativism was not a significant predictor.

When investigating the no harm/ no foul activities (CE3), only idealism and Machiavellianism constructs enter the model as significant. However, the explanatory power of the model drops substantially $\left(R^{2}=0.041\right)$. Idealism again was found to be the most influential variable in this equation $(\beta=-0.136, p<0.05)$. Consumers who were Machiavellist would be more likely, as indicated by the positive sign, to consider no harm / no foul activities acceptable ( $\beta=0.132$, $\mathrm{p}<0.05$ ).

For the last dimension, "recycling/ doing good" (CE4), the three independent variables explained only $8.4 \%$ of the variance in the dependent variable. Idealism was the most important and the only significant contributor to the equation $(\beta=$ $0.288, p<0.05)$. The direction of the positive sign indicates a parallel relationship between idealism and recycling/ doing good. This implies that Malaysian consumers who adhere to an idealistic moral ideology would be the one most likely to engage in recycling activities or doing good; for example correcting a bill that has been miscalculated in their favor. 
Table 5 provides a summary on the influence of the three independent variables to consumer ethics as were discussed previously.

\begin{tabular}{|l|c|c|c|}
\hline \multirow{2}{*}{ Dependent variables } & \multicolumn{2}{|c|}{ Independent variables } \\
\cline { 2 - 4 } & Relativism & I dealism & Machiavellianism \\
\hline $\begin{array}{l}\text { Actively benefiting from } \\
\text { illegal activities (CE1) }\end{array}$ & No influence & Greatest influence & Significant influence \\
\hline $\begin{array}{l}\text { Benefiting from } \\
\text { questionable activities } \\
\text { (CE2) }\end{array}$ & No influence & Greatest influence & Significant influence \\
\hline $\begin{array}{l}\text { No harm / no foul (CE3) } \\
\text { Recycling / doing good } \\
\text { (CE4) }\end{array}$ & No influence & Greatest influence & Significant influence \\
\hline
\end{tabular}

Table 5. Summary results of the regression models.

\section{A comparison of current study with Singhapakdi et al. (1999)}

Ten years have passed since Singhapakdi et al. (1999) did a study comparing Malaysian and US consumers. Table 6 summarized the comparison between the current research and the study by Singhapakdi et al. (1999).

\begin{tabular}{|l|l|l|}
\hline \multicolumn{1}{|c|}{ Study } & \multicolumn{1}{|c|}{ Population sampled } & Findings \\
\hline Singhapakdi et al. (1999) & $\begin{array}{l}\text { US and Malaysian } \\
\text { consumers (US }=283, \\
\text { Malaysia=216) }\end{array}$ & $\begin{array}{l}\text { Malaysian consumers tend to } \\
\text { be less idealistic and more } \\
\text { relativistic in their moral } \\
\text { philosophies than US } \\
\text { consumers. }\end{array}$ \\
\hline Current research & $\begin{array}{l}\text { Malaysian consumers were less } \\
\text { sensitive to unethical marketing } \\
\text { practices than US consumers. }\end{array}$ \\
\hline Malaysian consumers & $\begin{array}{l}\text { Malaysian consumers were } \\
\text { found to be more idealistic in } \\
\text { all the consumer ethics } \\
\text { measures. } \\
\text { Supportive in doing good and } \\
\text { recycling }\end{array}$ \\
\hline
\end{tabular}

Table 6. Comparison of current study with that of Singhapakdi et al. (1999).

Singhapakdi et al. (1999) revealed that Malaysian consumers in 1999 tend to be less idealistic and more relativistic in their moral philosophies than US consumers. Furthermore the study also discovered that Malaysian consumers were less sensitive to unethical marketing practices than US consumers. Comparing Singhapakdi et al. (1999) study with the current research, it is noted that 
Malaysian consumers have evolved over the last ten years to be more idealistic in their moral ideology.

\section{Discussion}

Malaysian consumers were found to be idealistic in all the four consumer ethical dimensions. When faced with ethical dilemma to actively benefit from illegal activities or to benefit from questionable activities, the main stance of Malaysian consumers would be to reject these unethical practices. Although Machiavellianism was also found to exert significant influence on CE1 and CE2, it was less influential compared to idealistic ideology. Idealism also exerts the greatest influence in the case of no harm / no foul activities. This means that even in the instance where these activities might be perceived by many to cause no harm to others such as downloading music from the Internet instead of buying it, Malaysian consumers would reject it as un-ethical. It is also heartening to know that Malaysian consumers support recycling efforts and putting a lot of emphasis on doing good and the protection of the environment. A closer scrutiny on the demographic of the respondents however reveals that the sample is skewed towards highly educated and professional group. Education has been found to be related to ethical decisionmaking. In general, people who are more educated tend to make more ethical decisions (Goolsby \& Hunt, 1992; Kelley et al., 1990). Perhaps this might explain the great influence exerted by idealistic ideology on all the four dimensions.

International companies operating in Malaysia will find the results of the present study useful for various reasons. First, from retailers' perspective, shrinkage attributable to consumers such as shoplifting, fraudulent returns, price alterations etc may represent less of a threat to profit margins for the current Malaysian consumers compared to the Malaysian market ten years ago. Such a situation would have the dual benefit to retailers of both reducing shrinkage costs as well as the cost of security measures designed to combat such shrinkage. Secondly, another area in which marketers may consider the results of this study is through the use of advertising appeals presented. By associating the consumption of a particular good or service with ethical behavior, firms, particularly those identified as having a strong record of protecting the environment as well as firms that treat their employees fairly may strike a positive chord with Malaysian consumers. 
Malaysian consumers in this study provided some evidence that they are concerned about ethical issues and are less likely to engage in unethical behaviors such as using pirated software and shoplifting. This finding would suggest that using ethical appeals which emphasized on the moral implications of engaging in unethical behavior might be an effective tool in addressing ethical issues. Both government and marketers may draw on ethical appeals in reaching out to consumers through advertising and public service announcements. However, on the other hand, for certain group of consumers, ethical appeals may not work since this group of consumers may not perceive unethical behavior as unacceptable. The remedy might for the government to take punitive measures in law enforcement rather than ethical appeal. A combination of both ethical appeal as well as enhancing the enforcement of the law might be more effective measures in reducing unethical consumer behavior.

\section{Conclusions}

There are some limitations to this research that need to be considered. First of all, some of the statements in the questionnaire may not be totally relevant to the culture of Malaysian consumers although modifications were made to some of the statements in this study. Future research would probably benefit by conducting a focus group from consumer experts by seeking the opinions on relevant statements that truly reflect Malaysian consumers. Secondly, the questionnaire for this research is in English. Considering that Malaysia is a very diverse country with many languages, some participants may have difficulty in understanding the questions asked. This may be overcome by translating the questionnaire into Malay, Chinese or even Tamil. Another limitation is the sampling method through the Internet. This would exclude Malaysian populations who do not have access to the Internet. Utilization of several sampling methods would be useful to ensure a truly representative of the Malaysian population.

The study provides an important insight into the research on consumer ethics in Malaysia and contributes to current literatures of consumer ethics by providing new evidences from Malaysia. Future study should consider the effect of demographic factors such as gender, age, education level, marital status and place of residence on consumer ethical behavior. Secondly, the questionnaire only asked if consumers had ever engaged in the stated activities. This gives little indication of their frequency of occurrence. Future research should probably measure the frequency of The good, the bad and the ugly: The shifting ethical stance of Malaysian consumers 


\section{- Intangible Capital}

Intangible Capital, 2010 - 6(2): 236-257 - ISSN: 1697-9818

doi:10.3926/ic.2010.v6n2.p236-257

these activities and this would be useful for identifying the worst activities and estimating cost implications. It is also recommended that the study be replicated in other Southeast Asian market, as what constitutes unethical behavior in one country may be acceptable in another. A comparative study between developed and developing Asian consumer market should also be considered.

\section{References}

AL-KHATIB, J.A.; ROBERTSON, C.J.; STANTON, A.D.; AND VITELL, S.J. (2002). Business ethics in the Arab Gulf states: A three-country study. International Business Review, 11(1): 97-111. doi:10.1016/S0969-5931(01)00049-X

AL-KHATIB, J.A.; VITELL, S.J.; AND RAWWAS, M.Y.A. (1997). Consumer ethics: A cross-cultural investigation. European Journal of Marketing, 31(11/12): 750767. doi: $10.1108 / 03090569710190514$

ANG, S.W.; CHENG, P.S.; LIM, E.A.C.; AND TAMBYAH, S.K. (2001). Spot the difference: Consumer responses towards counterfeits. Journal of Consumer Marketing, 18(3): 219-235. doi: 10.1108/07363760110392967

BERNSTEIN, P. (1985). Cheating- the new national past-time? Business, OctoberDecember: 24-33.

BONSU, S.K.; AND ZWICK, D. (2007). Exploring consumer ethics in Ghana, West Africa. International Journal of Consumer Studies, 31: 648655. doi: $10.1111 /$ j.1470-6431.2007.00616.x

CALHOON, R. (1969). Niccolo Machiavelli and the twentieth administrator. Academy of Management J ournal, 12: 205-212. doi: 10.2307/254816

CHAN, A.; WONG, S.; AND LEUNG, P. (1998). Ethical beliefs of Chinese consumers in Hong Kong. Journal of Business Ethics, 17(11): 11631171. doi: 10.1023/A: 1005760729697

CHONKO, L.B.; AND HUNT, S.D. (1985). Ethics and marketing management: An empirical examination. Journal of Business Research, 13(4): 339359. doi: 10.1016/0148-2963(85)90006-2 


\section{- Intangible Capital}

Intangible Capital, 2010 - 6(2): 236-257 - ISSN: 1697-9818 doi: 10.3926/ic.2010.v6n2.p236-257

CHRISTIE, R.; AND GEIS, F.L. (1970). Studies in Machiavellianism. New York: Academic Press.

DODGE, H.R.; EDWARDS, E.A.; AND FULLERTON, S. (1996). Consumer transgressions in the marketplace: Consumer's perspectives'. Psychology and Marketing, $\quad$ 18(8): 821-835. doi: $10.1002 /(\mathrm{SICI}) 1520-$ 6793(199612)13:8<821::AID-MAR7>3.0.CO;2-H

ERFFMEYER, R.C.; KEILLOR, B.D.; AND LECLAIR, D.T. (1999). An empirical investigation of Japanese consumer ethics. J ournal of Business Ethics, 18(1): 3550. doi: 10.1023/A: 1006025724126

EUROPEAN RETAIL THEFT BAROMETER (2006). University of Nottingham Center for Retail Research.

FORSYTH, D.E. (1992). Judging the morality of business practices: The influence of personal moral philosophies. Journal of Business Ethics, 11(5/6): 461470. doi: 10.1007/BF00870557

FULLERTON, S.; TAYLOR, D.; AND GHOSH, B.C. (1997). A cross-cultural examination of attitudes towards aberrant consumer behavior in USA, New Zealand and Singapore. Marketing Intelligence and Planning, 15(4/5): 208213. doi: $10.1108 / 02634509710177215$

GOOLSBY, J.R.; AND HUNT, S.D. (1992). Cognitive moral development and marketing. Journal of Marketing, 56(J anuary): 55-68. doi: 10.2307/1252132

HAIR, J.F.; ANDERSON, R.E.; TATHAM, R.L.; AND BLACK, W.C. (1998). Multivariate data analysis. New Jersey: Prentice Hall International, Inc.

HAIR, J.F.; MONEY, A.H; SAMOUEL, P.; AND PAGE, M. (2007). Research Methods for Business. Hoboken, New J ersey: John Wiley \& Sons.

HUNT, S.D.; AND CHONKO, L.B. (1984). Marketing and Machiavellianism. Journal of Marketing, 48: 30-42. doi: 10.2307/1251327

KELLEY, S.W.; FERRELL, O.C.; AND SKINNER, S.J . (1990). Ethical behavior among marketing researchers: An assessment of selected demographic characteristics. Journal of Business Ethics, 9(August): 681-688. doi: 10.1007/BF00383395 


\section{- Intangible Capital}

Intangible Capital, 2010 - 6(2): 236-257 - ISSN: 1697-9818

doi: 10.3926/ic.2010.v6n2.p236-257

KENHOVE, P.V.; VERMEIR, I.; AND VERMEIRS, S. (2001). An empirical investigation of the relationships between ethical beliefs, ethical ideology, political preference and need for closure of Dutch-speaking consumers in Belgium. Journal of Business Ethics, 32(4): 347-361. doi: 10.1023/A:1010720908680

LAU, T.C.; CHOE, K.L.; AND RAMLY, Z. (2009). Exploring ethical orientation of future business leaders in Malaysia. International Review of Business Research Papers, 5(2): 109-120.

MCDANIEL, C.; AND GATES, R. (2008). Marketing Research Essentials. Hoboken, New J ersey: John Wiley $\&$ Sons.

MCGEE, R.W. (1992). Business Ethics and Common Sense. Westport, Connecticut: Quorum Books.

MCHOSKEY, J.W.; HICKS, B.; BETRIS, T.; SZYARTO, C.; WORZEL, W.; KELLY, K. (1999). Machiavellianism, adjustment and ethics. Psychological Reports, 85(1): 138-142. doi: 10.2466/PR0.85.5.138-142

MUNCY, J.A.; AND VITELL, S.J. (1992). Consumer ethics: An empirical investigation of the ethical beliefs of the final consumer. Journal of Business Research, 24(1): 297-312. doi: 10.1016/0148-2963(92)90036-B

NUNNALLY, J.C. (1978). Psychometric Theory. New York: McGraw-Hill.

POLONSKY, M.J.; BRITO, P.Q.; PINTO, J.; AND KLEYN, N.H. (2001). Consumer ethics in the European Union: A comparison of Northern and Southern view. J ournal of Business Ethics, 31(May): 117-130. doi: 10.1023/A: 1010780526643

RAO, C.P.; AND AL-WUGAYAN, A.A. (2005). Gender and cultural differences in consumer ethics in a consumer retailer interaction context. Journal of International Consumer Marketing, 18(1/2): 45-71. doi: 10.1300//046v18n01_03

RAWWAS, M.Y.A. (1996). Consumer ethics: An empirical investigation of the ethical beliefs of Austrian consumers. Journal of Business Ethics, 15(9): 10091019. doi: 10.1007/BF00705579

RAWWAS, M.Y.A. (2001). Culture, personality and morality: A typology of international consumers ethical beliefs. International Marketing Review, 18(2): 188-211. doi: 10.1108/02651330110390006 


\section{- Intangible Capital}

Intangible Capital, 2010 - 6(2): 236-257 - ISSN: 1697-9818 doi: 10.3926/ic.2010.v6n2.p236-257

RAWWAS, M.Y.A.; AND SINGHAPAKDI, A. (1998). Do consumers' ethical beliefs vary with age? A substantiation of Kohlberg's typology in Marketing. Journal of Marketing Theory \& Practice, 6(2): 26-38.

RAWWAS, M.Y.A.; PATZER, G.L.; AND KLASSEN, M.L. (1995). Consumer ethics in cross-cultural settings: Entrepreneurial implications. European Journal of Marketing, 29(7): 62-78. doi: 10.1108/03090569510095017

RAWWAS, M.Y.A.; STRUTTON, D.; AND JOHNSON, L.W. (1996). An exploratory investigation of the ethical values of American and Australian consumers'. J ournal of Direct Marketing, 10(Autumn): 52-63. doi: 10.1002/(SICl)15227138(199623)10:4<52::AID-DIR5>3.0.CO;2-W

RAWWAS, M.Y.A.; VITELL, S.J.; AND AL-KHATIB, J.A. (1994). Consumer ethics: The possible effects of terrorism and civil unrest on the ethical values of consumers. J ournal of Business Ethics, 13(3): 223-231. doi: 10.1007/BF02074821

SCHLENKER, B.R.; AND FORSYTH, D.R. (1977). On the ethics of psychological research. Journal of Experimental Social Psychology, 13(4): 369396. doi: 10.1016/0022-1031(77)90006-3

SHEN, D.; AND DICKSON, M.A. (2001). Consumers' acceptance of unethical clothing consumption activities: Influence of cultural identification, ethnicity, and Machiavellianism. Clothing and Textiles Research Journal, 19(2): 7687. doi: $10.1177 / 0887302 \times 0101900204$

SILVERMAN, D. (1999). Who's minding the store theft? Shoplifters and employees cost retailers $\$ 26$ Billion in 1998 but help is available. Daily News Record, May: 1041-1119.

SINGHAPAKDI, A.; KRAFT, K.L.; VITELL, S.J.; AND RALLAPALLI, K.C. (1995). The perceived importance of ethics and social responsibility on organizational effectiveness: A survey of marketers. Journal of the Academy of Marketing Science, 23(1): 49-56. doi: 10.1007/BF02894611

SINGHAPAKDI, A.; RAWWAS, M.Y.A.; MARTA, J.K.; AND AHMED, M.I. (1999). A cross-cultural study of consumer perceptions about marketing ethics. The Journal of Consumer Marketing, 16(3): 257-272. doi: 10.1108/07363769910271496 


\section{- Intangible Capital}

Intangible Capital, 2010 - 6(2): 236-257 - ISSN: 1697-9818 doi: 10.3926/ic.2010.v6n2.p236-257

STEENHAUT, S.; AND KENHOVE, P. (2006). An empirical investigation of the relationships among a consumer's personal values, ethical ideology and ethical beliefs. Journal of Business Ethics, 64: 137-155. doi: 10.1007/s10551-005-5905-3

STRUTTON, D.; VITELL, S.J.; AND PELTON, L.E. (1994). How consumers may justify inappropriate behavior in market settings: An application on the techniques of neutralization. Journal of Business Research, 30: 253260. doi: 10.1016/j.ibusrev.2004.09.002

SWAIDAN, Z.; RAWWAS, M.Y.A.; AND AL-KHATIB, J.A. (2004). Consumer ethics: Moral ideologies and ethical beliefs of a micro-culture in the US. International Business Review, 13: 749-761.

TAYLOR, P.W. (1975). Principles of Ethics: An Introduction. California: Dickensen.

THE STAR. (2009). Bribe and Prejudice. Sunday, September 27, 2009.

THE STAR. (2010). Additional 5,000 MACC Officers to Speed up Clearing Cases. Thursday, August 5, 2010.

THONG, J.Y.L.; AND YAP, C.S. (1998). Testing an ethical decision making theory: The case of softlifting. Journal of Management Information Systems, 15(Summer): 213-237.VITELL, S.J. (2003). Consumer ethics research: Review, synthesis and suggestions for the future. Journal of Business Ethics, 43: 33-47.

VITELL, S.J.; AND MUNCY, J. (2005). The Muncy-Vitell consumer ethics scale: A modification and application. Journal of Business Ethics, 62: 267275. doi: 10.1007/s10551-005-7058-9

VITELL, S.J.; LUMPKIN, J.R.; AND RAWWAS, M.Y.A. (1991). Consumer ethics: An investigation of the ethical beliefs of elderly consumers. Journal of Business Ethics, 10(5): 365-375. doi: 10.1007/BF00383238

VITELL, S.J.; SINGHAPAKDI, A.; AND THOMAS, J. (2001). Consumer ethics: An application and empirical testing of the Hunt-Vitell theory of ethics. Journal of Consumer Marketing, 18(2): 153-178. doi: 10.1108/07363760110386018

WIKES, R.E. (1978). Fraudulent behavior by consumers. Journal of Marketing, 42(Oct): 67-75. doi: $10.2307 / 1250088$ 
ZIKMUND, W.G. (2003). Business Research Methods, ( ${ }^{\text {th }}$ Ed.). Mason, Ohio: Thomson-South-Western.

Intangible Capital, 2010 (www.intangiblecapital.org)

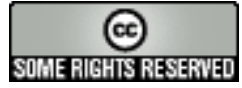

Article's contents are provided on a Attribution-Non Commercial 3.0 Creative commons license. Readers are allowed to copy, distribute and communicate article's contents, provided the author's and Intangible Capital journal's names are included. It must not be used for commercial purposes. To see the complete licence contents, please visit http://creativecommons.org/licenses/by-nc/3.0/es/ 